\title{
Radial Artery Pseudoaneurysm After Transradial Coronary Angiogram: A Mostly Overlooked Complication
}

\author{
Sıklıkla Atlanan Komplikasyon: Transradyal Koroner Anjiografi Sonrası Gelișen Radial Arter Psödoanevrizması
}

Veysel Özgür Barıș ${ }^{1}$ Özgür Ulaș Özcan ${ }^{1}$, İrem Müge Akbulut ${ }^{1}$, Eralp Tutar¹

Ankara University School of Medicine, Department of Cardiology

\begin{abstract}
Radial arter, tanısal ve girișimsel kalp kateterizasyon ișlemleri için önerilen güvenli girișim yeridir. Bu yazı mızda, antikoagülan tedavi altında transradial anjiografi olduktan 10 gün sonra radial arter psödoanevrizmas gelișen 73 yașında kadın olguyu takdim ettik. Ultrasonografi aracılı kompresyonun bașarısız olması nedeniyle, hastada cerrahi tedavi uygulandı. Antikoagülan tedavi altında transradial anjiografi yapılan hastalarda, ișlem sonrası dikkatli takip önermekteyiz.

Anahtar Sözcükler: Radyal Arter, Psödoanevrizma, Koroner Anjiografi, Komplikasyon

Radial artery is suggested as a safe access for diagnostic and interventional cardiac catheterization.We present a 73 year old female who was suffered a radial artery pseudoaneurysm 10 days after transradial coronary angiography while under anticoagulation therapy. Prolonged ultrasound guided compression was unsuccessful and the patient was treated with surgical repair. We suggest careful observation after transradial catheterization for patients under anticoagulant therapy.

Key Words: Radial Artery, Pseudoaneurysm, Coronary Angiogram, Complication
\end{abstract}

Transradial access is recommended during percutaneous coronary diagnostic and interventional procedures, especially among patients with acute coronary syndromes and patients under anticoagulation therapy. Radial artery is more favorable for vascular access than femoral artery because of owning some advantages in terms of lower incidence of bleeding events and earlier time for ambulation $(1,2)$. However, there also are complications related to transradial access (3). Radial artery pseudoaneurysm is an extremely rare complication with an incidence of $0.048 \%(3,4)$.

\section{Case Report}

A 73 year old female was presented to our clinic with refractory angina pectoris. Transthoracic echocardiogram revealed hypokinesis of mid and apical segments of anterior wall. She was under warfarin treatment for paroxysmal atrial fibrillation. The procedure was performed after warfarin had been ceased for 3 days. The patency of dual hand circulation was confirmed with positive modified Allen test. The International Normalized Ratio (INR) at the time of angiography was 1.5. Coronary angiography performed via the left radial artery using a 5Fr arrow introducer sheath (Arrow International, Reading, PA). Heparin (3000 IU) and verapamil $(5 \mathrm{mg})$ was given to prevent thrombosis and spasm respectively. Coronary angiogram revealed nonsignificant atherosclerotic plaques. The vascular sheath was removed immediately after the procedure and the puncture site was manually compressed for 15 minutes. Afterwards, a compressive dressing was applied for 24 hours. The next day, warfarin therapy was initiated again because of paroxysmal atrial fibrillation with a CHA2DS2-VASc score of 6. No sign of hematoma was determined on radial artery and the patient was discharged. Ten days after the radial artery puncture, the patient was noted a painful swelling with a small hematoma that appeared over the site of the radial access. She seeked attention 5 days after the symptom onset. Her INR level was 2.4 at that time. Colour Doppler ultrasound (Toshiba Diagnostic Ultrasound System, Model SSA-770A) revealed a $17 \mathrm{x} 10 \mathrm{~mm}$ sized pseudoaneurysm with 
a 1,6 mm neck communicating between the radial artery and the false aneurysm (Figure 1). Prolonged ultrasoundguided compression was attempted. However, it was unsuccessful. Therefore, the patient underwent surgical repair with ligation and excision of the pseudoaneurysm. After the surgical repair there was trombus formation in the radial artery (Figure 2) and no evidence of pseudoaneurysm was detected. Radial pulse and distal perfusion was preserved.

\section{Discussion}

Transradial access for percutaneous coronary procedure is considered as safe and convenient approach compared to the transfemoral access. However, the vascular complications associated with transradial access are not rare. It is essential for the interventional cardiologists to be aware of these complications. Symptomatic radial artery occlusion, non-occlusive radial artery injury and radial artery spasms are commonly reported complications of this approach (3). Pseudoaneurysm formation and radial artery perforation are rarely reported complications of transradial approach (5). In this case, we present a patient with radial artery pseudoaneurysm following percutaneous cardiac catheterization. There are many risk factors associated with pseudoaneurysm formation. These include; penetrating injury of the arterial wall during cannulation, multiple puncture attempts, catheter infection, aggressive anticoagulation therapy, and the use of large sized sheaths (3). In our case, none of these risk factors was present. The anticoagulation therapy was restarted the day after catheterization. Even suggested as a safe procedure transradial approach may warrant more careful observation particularly among patients on anticoagulant therapy and interventional cardiologists should be aware of the potential for such late access site complication.

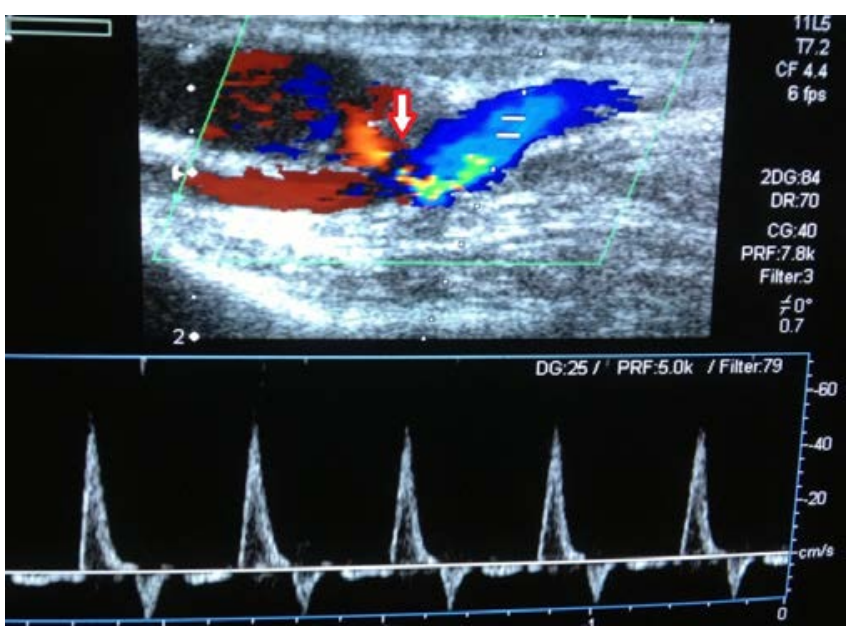

Figure 1: Arrow indicates $17 \times 10 \mathrm{~mm}$ sized pseudoaneurysm with a $1.6 \mathrm{~mm}$ neck communicating between the radial artery and the false aneurysm.

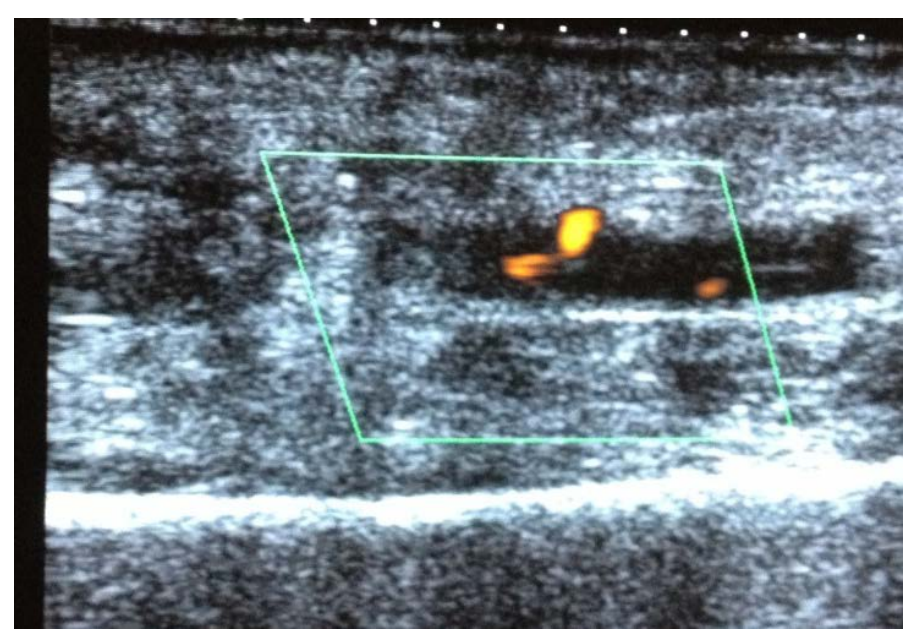

Figure 2: After the surgical repair there was trombus formation in the radial artery.

\section{REFERENCES}

1. Jolly SS, Yusuf S, Cairns J, et al. Radial versus femoral Access for coronary angiography and intervention in patients with acute coronarys yndromes (RIVAL): a randomised, parallelgroup, multicentretrial. Lancet. 2011;377:1409-1420.

2. Romagnoli E, Biondi-Zoccai $G$, Sciahbasi A, et al. Radial versus femoral randomized investigation in ST-segment elevation acute coronary syndrome: the RIFLESTEACS (Radial Versus Femoral Randomized Investigation in ST-Elevation Acute Coronary Syndrome) study. J Am Coll Cardiol.2012;60:2481-2489.

3. Kanei Y, Kwan T, Nakra NC, et al. Transradial cardiac catheterization: a review of access site complications. Catheter Cardiovasc Interv. 2011;78:840-846.
4. Collins N, Wainstein R, Ward M, et al. Pseudoaneurysm after transradial cardiac catheterization: case series and review of the literature. Catheter Cardiovasc Interv. 2012;80:283-287.

5. Bhat $\mathrm{T}$, Bhat $\mathrm{H}$, Teli $\mathrm{S}$, et al. Pseudoaneurysm a rare complication of transradial cardiac catheterization: a case report. Vascular. 2013 Mar 18. 